\title{
Impacts of stress on employees job performance in Hawassa Industrial Park, Ethiopia
}

\author{
Girma Melese Mengistu ${ }^{1}$ and Hao Jinxing ${ }^{1}$ \\ School of Economics and Management, Beihang University, Beijing 100191, China
}

\begin{abstract}
This paper aims to explore the impacts of stress on employees' job performance with a specific focus on Hawasa Industrial Park in Ethiopia. Data was collected through key interviews, household survey and field observation. For the survey, 394 randomly selected respondents were interviewed. The results indicate that the dependent variable (job performance) related positively with education (EDU), working experience (WEX) and age (Age). The relation between gender and job performance is negative but insignificant since the value of betta coefficient is greater than 0.05 . Based on this result, working experience showing a higher value $(\mathrm{r}=.438, \mathrm{p}<.01)$ followed by education $(\mathrm{r}=.114, \mathrm{p}<.05)$ and age $(\mathrm{r}=.032, \mathrm{p}<.05)$. We identified that workload (18\%), conflict at work (29\%), role ambiguity (20\%) and resource inadequacy (33\%) are reported as the major causes of stress in the organization. Hence, this study suggests awareness creation campaigns for all the working staffs including the management are necessary to at least reduce stress and low performance of organization.
\end{abstract}

\section{INTRODUCTION}

Human resource is the most critical one that makes a difference in organizational performance from other organizational resources (Becker and Gerhart 1996, Anderson 2003). For employees to work for an organization with interest and commitment, managers in any sector are expected to perform different managerial activities including stress management. Job performance is the accomplishment of job-related tasks or skills by an employee or trainee to the specific skills. (Prager 2016) noted that the employee's ability to perform their job effectively requires understanding of up to date job description the job performance requirements and standards that are expected to meet based on employee position. Stress comes when there is a serious of pressure or demands rested on the shoulder of human beings. Different studies noted that working environment, support from the management and work overload are few of the factors that instigates stress (Stebbins 2001). Bashir and Ismail Ramay (2010) also noted that conflicts within a family can also be a source of conflict in an organization. Due to these interrelated factors, employees' job performance in an organization would be negatively affected. In addition, employees would be dissatisfied in their work, role and responsibilities (Aziz 2012).Several recent studies (Omisore 2014, Isa 2015, Palomino and Frezatti 2016) noted that personal differences in perceptions and expectations, misinformation and misrepresentation, role ambiguity in goals and responsibilities and environmental stress are the sources of conflict. Personal differences are caused by different individual roles in organizations largely influenced by cultural and family traditions, level of education, experience and so on. Scarcity of information- important messages may not be received; a boss's instructions may be misinterpreted. Role incompatibility comes from misunderstanding of roles and responsibilities in an organization. Environmental conflicts arise from a frustration of losing jobs.

\section{RESEARCH OBJECTIVE AND HYPOTHESIS}

The main research objective is to explore to explore whether the employees in the Hawasa Industrial Park are influenced by stress and how does it impact their job performance in the company. Accordingly, we make our hypothesis as follows:

H1. Stress is one of the major factors that influences employee job performance

H2. Work load, work conflict, resource adequacy and role ambiguity are the causes of stress

\section{RESEARCH METHODOLOGY}

This study is carried out in the Hawasa Industrial Park, located in southern Ethiopia. Based on the Cochran (1977) formula, the sample size was determined to be 394. A simple random sampling procedure was used in consideration with similar proportions. Both qualitative and quantitative methods were used. Qualitative method is useful to explore employees' opinions, attitudes, behaviors, and experiences of the respondents. We collected data through a serious of interviews, field observation, focus

Email: girmagbdr@yahoo.com 
group discussion (FGD), and household survey. Interview and FGD were made with office heads, managers and employees about the causes, effects, and management of stress. A structured questionnaire based on relevant literature was prepared and pre-tested. The questionnaire includes information on socio-economic and demographic characteristics of the respondents. Moreover, relevant literature and reports were referred. With regard to analysis, descriptive and inferential statistics were used to analyze the quantitative data. The data was edited, coded, organized and analyzed using Statistical Package for Social Sciences (SPSS). Moreover, Linear Regression was employed. The independent variables were workload, role ambiguity, resource inadequacy and conflict at work while the dependent was job performance. In addition, the qualitative data was analyzed using content analysis.

\section{Results}

\subsection{Socio- economic and demographic characteristics of respondents}

The study reveals that $70.9 \%$ of the respondents were male, while $29.1 \%$ were female. $39.8 \%$ of the respondents were between the ages of $30-39$ while $35.9 \%$ of the respondents were between $20-29.15 .5 \%$ and $8.7 \%$ of the respondents were between the age of 40-49 and above 50 years old, respectively. $82.5 \%$ attended higher education while the rest $17.5 \%$ attended secondary school. The majority (46.6\%) had a work experience of $1-5$ years; while $24.3 \%$ of them had an experience of 6-10 years. 45 and $42 \%$ of the respondents are married and single, respectively. However, $10 \%$ of them are divorced and widowed. Less than $90 \%$ of the employees are daily laborer, while the rest are case team leaders, process owners, and managers. All respondents are permanent. About $55 \%$ of the respondents have a salary of less than 3000 and an estimated $30 \%$ with less than 4000 , while $20 \%$ of them earned less than 2000 Ethiopian birr.

\subsection{Correlation analysis}

4.2.1 Correlations analysis: Major causes with job performance

Table1. Correlations analysis: Major causes with job performance

\begin{tabular}{|l|l|l|l|l|l|l|}
\hline \multirow{2}{*}{ JP } & $\begin{array}{l}\text { Pearson } \\
\text { Correlation }\end{array}$ & 1 & WPA & WOL & WC & RA \\
\cline { 2 - 7 } & Sig. (2-tailed) & & & & & \\
\hline \multirow{3}{*}{ WA } & $\begin{array}{l}\text { Pearson } \\
\text { Correlation }\end{array}$ & .071 & 1 & & & \\
\cline { 2 - 8 } & Sig. (2-tailed) & .475 & & & & \\
\hline \multirow{3}{*}{ WOL } & $\begin{array}{l}\text { Pearson } \\
\text { Correlation }\end{array}$ & $.885^{* *}$ & .156 & 1 & & \\
\cline { 2 - 8 } & Sig. (2-tailed) & .000 & .115 & & & \\
\hline \multirow{3}{*}{ WC } & $\begin{array}{l}\text { Pearson } \\
\text { Correlation }\end{array}$ & .167 & $-.218^{*}$ & -.191 & 1 & \\
\cline { 2 - 8 } & Sig. (2-tailed) & .091 & .027 & .053 & & \\
\hline \multirow{2}{*}{ RA } & $\begin{array}{l}\text { Pearson } \\
\text { Correlation }\end{array}$ & .009 & .016 & .157 & .175 & 1 \\
\cline { 2 - 8 } & Sig. (2-tailed) & .930 & .872 & .114 & .076 & \\
\hline
\end{tabular}

$* *$. Correlation is significant at the 0.01 level (2-tailed).

*. Correlation is significant at the 0.05 level (2-tailed).

\subsubsection{Correlation of demographic data with job performance}

Table2. Correlation of demographic data with job performance

\begin{tabular}{|l|l|r|r|r|r|r|}
\hline \multicolumn{2}{|c|}{} & \multicolumn{1}{|c|}{ GNDR } & \multicolumn{1}{|c|}{ AGE } & EXP & EDU & EJP \\
\hline \multirow{2}{*}{ Gender } & Pearson Correlation & 1 & & & & \\
\cline { 2 - 7 } & Sig. (2-tailed) & & & & & \\
\hline \multirow{2}{*}{ Age } & Pearson Correlation & -.036 & 1 & & & \\
& Sig. (2-tailed) & .721 & & & & \\
\cline { 2 - 7 } & N & 394 & 394 & & & \\
\hline \multirow{2}{*}{$\begin{array}{l}\text { Experien } \\
\text { ce }\end{array}$} & Pearson Correlation & .087 & .090 & & & \\
\cline { 2 - 7 } & Sig. (2-tailed) & .383 & .365 & & & \\
\hline
\end{tabular}




\begin{tabular}{|c|c|c|c|c|c|c|}
\hline & $\mathrm{N}$ & 394 & 394 & 394 & & \\
\hline \multirow[t]{3}{*}{ Edu } & Pearson Correlation & .176 & .091 & .021 & 1 & \\
\hline & Sig. (2-tailed) & .076 & .360 & .835 & & \\
\hline & $\mathrm{N}$ & 394 & 394 & 394 & 394 & \\
\hline \multirow[t]{3}{*}{ EJP } & Pearson Correlation & .069 & .032 & $.438^{* *}$ & .114 & 1 \\
\hline & Sig. (2-tailed) & 491 & $.040^{*}$ & .000 & $.031^{*}$ & \\
\hline & $\mathrm{N}$ & 394 & 394 & 394 & 394 & 394 \\
\hline
\end{tabular}

The dependent variable (job performance) related positively with the education (EDU), working experience (WEX) and age $(\mathrm{Ag})$. The relation between gender and job performance is negative but insignificant since the value of betta coefficient is greater than 0.05 .

Based on this, working experience showing a higher value $(\mathrm{r}=.438, \mathrm{p}<.01)$ followed by education $(\mathrm{r}=.114$, $\mathrm{p}<.05)$ and age $(\mathrm{r}=.032, \mathrm{p}<.05)$.

\subsection{Regression result Coefficientsa}

Table3. Regression result Coefficients

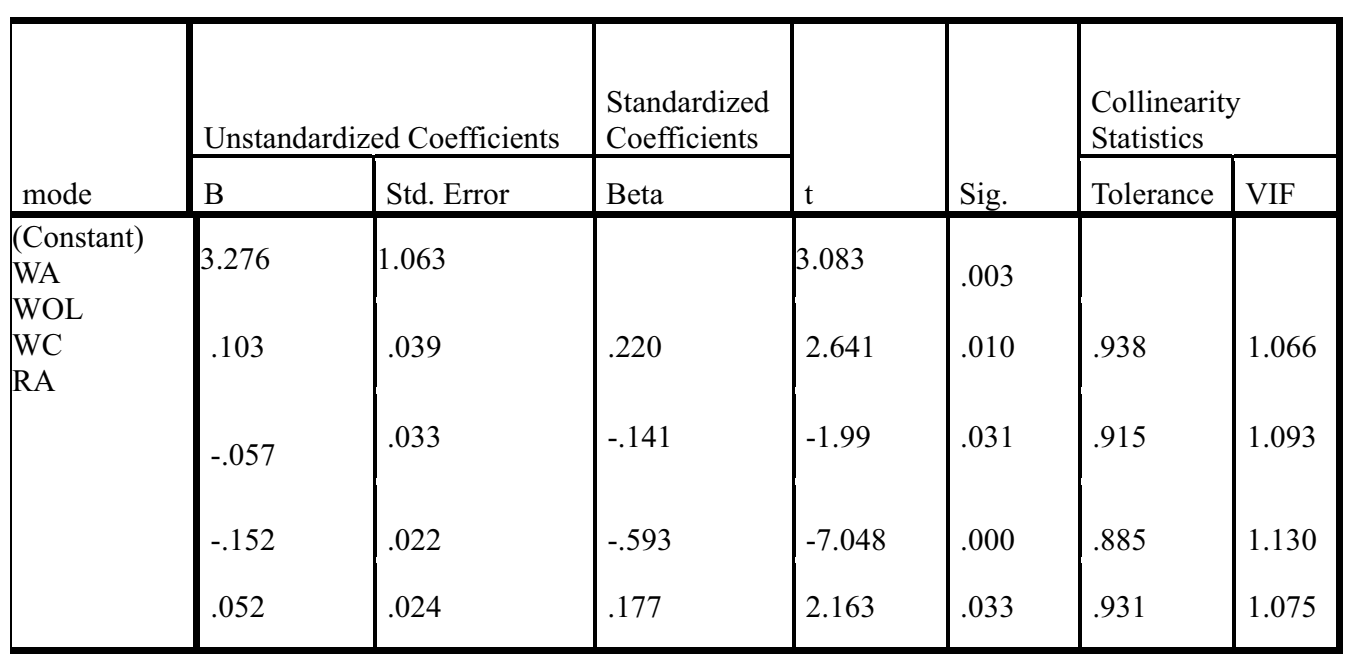

All the independent variables such as work overload, work conflict, role ambiguity, and resource deficiency) shows significant and positive association with job performance at $(\mathrm{P}<0.01)$ and at $(\mathrm{P}<0.05)$ level of confidence.

\section{Discussions}

Every employee wants a luxurious life, high income, promotion, etc. In order to increase the performance of an organization, lots of burden might be unintentionally exerted on employees. This might have a negatively influence the employee's mental and physiological health (Munir 2019). Work related stress is also most likely a cause for lower performance of employees in an organization. (Danna and Griffin 1999) finds that "workplace stress has been increasingly quoted as the main cause of accidents, job dissatisfaction, morbidity, and other physiological illnesses." As (Edwards and Burnard 2003) highlights managing the causes of stress is still not to come, however, it is still possible to reduce. We also understood from the focus group discussion that when employees are work loaded, they would be stressed, and cannot complete the given tasks properly and perform tasks below the standard of the organization. Stressed people will encounter difficulty in giving attention to work, rather focusing on how to deal with the stress, thus, quality of work would be reduced because stress is capable of weakening and diverting the attention of employees and raises overwork.

\section{Conclusions}

The major causes of stress are found to be work overload, work conflict, role ambiguity, and resource inadequacy, which reduce employees work performance. From such facts, role ambiguity was the major factor for stress among employees. Regarding the relationships and influence of the four selected independent variables a dependent variable that is job performance, a multiple linear regression was used. Based on the statistical significances of the independent variable over the dependent variable at 
$5 \%$ level of significance, all the independent variables (work overload, work conflict, work ambiguity, and resource adequacy) are significantly contributed for the job performance at $(\mathrm{P}<0.01)$ and at $(\mathrm{P}<0.05)$ level of confidence. The $\mathrm{R}^{2}$ value depicted that the four variables moderately explained which 38.6 is $\%(\mathrm{R} 2=0.386)$ of the variation in the employee job performance, the rest $61.4 \%$ are other variables not included in this study. Employees whose job expectations are in contradiction with each other and whose roles are ambiguous are bound to be frustrated and stressed. Despite such a problem, the organization poorly managed the stress of the employees. But since stress-free life is not possible in any organization, it cannot be completely eliminated.

We also conclude that it is possible to control stress and even the employees are capable of controlling their feelings and manage the cause of stress. It is very crucial for the employees to know each other and share values, experiences, opinions, exposures and ambition. This can primarily reduce stress among employees, which in turn can contribute for the successful accomplishment of the industrial park's mission and vision.

Stress factors are not always stable, consistent and similar to a group of occupations. It varies from environment to environment, work to work or situation to situation. Generally, management of the organization also plays an important role in evaluating and managing the stress level of employees at the workplace and should use different methods to minimize the stress such as conducting training courses to assist the employee's skills, providing better working environment and making sure that the employees get proper guidance and consultation when it's needed.

\section{REFERENCES}

1. Anderson, R. (2003). "Stress at work: the current perspective." The journal of the Royal Society for the Promotion of Health 123(2): 81-87.

2. Aziz, M. (2012). "Occupational role stress: a study of Indian business process outsourcing employees." Mediterranean Journal of Social Sciences 3(9): 103109.

3. Bashir, U. and M. Ismail Ramay (2010). "Impact of stress on employees job performance: A study on banking sector of Pakistan." Bashir, U., \& Ramay, MI (2010). Impact Of Stress On Employees Job Performance A Study On Banking Sector Of Pakistan. International Journal of Marketing Studies 2(1): 122126.

4. Becker, B. and B. Gerhart (1996). "The impact of human resource management on organizational performance: Progress and prospects." Academy of management journal 39(4): 779-801.

5. Danna, K. and R. W. Griffin (1999). "Health and wellbeing in the workplace: A review and synthesis of the literature." Journal of management 25(3): 357-384.

6. Edwards, D. and P. Burnard (2003). "A systematic review of stress and stress management interventions for mental health nurses." Journal of advanced nursing 42(2): 169-200.

7. Isa, A., Ahmed., (2015). "Conflicts in Organizations: Causes and Consequences " Journal of Educational Policy and Entrepreneurial Research 2 (11): 54-59

8. Munir, S. (2019). Impact of supportive work Environment on Employee Retention: Moderation Effect of Perceived Organizational Politics, Department of Management Science, COMSATS University Islamabad, Lahore campus.

9. Omisore, B., Oladosu, (2014). "Organizational Conflicts: Causes, Effects and Remedies." International Journal of Academic Research in Economics and Management Sciences 3(6): 118-137.

10. Palomino, M. and F. Frezatti (2016). "Role conflict, role ambiguity and job satisfaction: Perceptions of the Brazilian controllers." R.Adm., São Paulo 51(2): 165181.

11. Prager, R. Y. (2016). "The Effects of Goal Orientation and Learning Strategies on Managerial Job Performance."

12. Stebbins, L. F. (2001). Work and family in America: A reference handbook, ABC-CLIO. 